\title{
MAPPING URBAN WATER GOVERNANCE MODELS IN THE SPANISH MEDITERRANEAN COASTLINE
}

\author{
RUBÉN VILLAR \& ANA ARAHUETES \\ Instituto Interuniversitario de Geografía, Universidad de Alicante, Spain
}

\begin{abstract}
The heterogeneity of governance and management models of municipal water supply in the Spanish Mediterranean coastline has increased in recent decades. This diversity is explained by the increase of private companies responsible for the management of the local water service and the presence of supramunicipal public entities responsible for water catchment, treatment and distribution to the municipalities. Based on the review of the existing literature, the information available on the websites of the leading corporate groups in the water sector and contacting with councils, the companies and supramunicipal entities involved in the service of municipal water in the Mediterranean coastline have been identified. The objective of this work is to analyse the territorial presence of the main actors in the urban water management through its cartographic representation, as well as analyse its ownership and importance in terms of population supplied. This analysis shows a high presence of companies belonging to the AGBAR group that supply around half of the total population in the Spanish coastline municipalities. Likewise, there is a regional specialization of certain private companies that concentrate the urban water management for the most part of the coastline municipalities. This is the case of FACSA, which manages the water services in $87 \%$ of coastline municipalities in Castellón, or Hidraqua in Alicante, that operates in the $65 \%$. Furthermore, the presence of large supramunicipal public entities is widespread along the coastline, especially in Catalonia and the southeast. In contrast, some municipalities of the Balearic Islands reflect a singular situation, characterized by the presence of several different companies within the same municipality, both public and private. In the light of these results, the urban water management in the Spanish Mediterranean coastline shows the dominance of the private sector, which is present in the $82 \%$ of the municipalities.
\end{abstract}

Keywords: urban water governance, urban water management, privatisation, water companies, privatisation, AGBAR, FCC, supramunicipal entities, Mediterranean coastline, Spain.

\section{INTRODUCTION}

Over the past few decades different governance models have been developed in Spain as a result of increased private urban water management. This has produced a situation characterized by the heterogeneity of the supply systems and the management methods [1]. In Spain, as in many other countries, the municipalities are responsible for the management of urban water supply services, sanitation and wastewater treatment, in accordance with the Law 7/1985, $2^{\text {nd }}$ April, Regulating Local Regime Basis. This law allows municipalities to choose between different forms of urban water management, which can be managed directly by the municipality or by a public, a private company or a public-private partnership, also called mixed company. Even tough municipalities can privatize the management of the water services, infrastructure assets, price controls and financing still belong to the public sector [1]. Likewise, to take advantage of economies of scale and enhancing supply systems efficiency, many municipal associations have been set up. The emergence of consortiums and supramunicipal companies has allowed reducing the averages cost of the upstream water supply, which encompasses the processes of capture, treatment and distribution of water to the municipalities.

In the Mediterranean area, the presence of the private sector in the management of the urban water service is not new, as shown by the cases of Agbar in Barcelona [2], or Alicante, where is located the first mixed company in the water sector, founded in 1953 [3]. However, 
privatization of the municipal water service has increased since the 1980s. There are many reasons for this, although the main ones were pragmatic. The inability of municipalities to self-financing along with the increasing investment requirements in urban water services due to urban growth, tourism development and European water directives favoured the privatization [4], [5]. This wave of privatization has placed Spain among the OECD countries where there is a greater participation of the private sector in the management of urban water supply in terms of population served. Only England, Wales, France and the Czech Republic have a greater presence of the private sector [6]. As a result, the percentage of population supplied by the private sector has gone from $36 \%$ to 55\% between 1990 and 2014 [1], [7].

The intensity of this process has been greater in the Spanish Mediterranean area, since its geographical characteristics and business expectations favoured the private sector growth. In Mediterranean coastline, the scarcity of water resources, the overexploitation of aquifers, urban growth or seasonal variations in water consumption are factors that hamper the urban water management, which requires greater investments and technical knowledge [8]. Furthermore, the arrival of private companies is related to the concentration of the population and the consequent economic expectation. Indeed, in the Mediterranean coastal provinces are concentrated $41 \%$ of Spanish population and $20 \%$ in the Mediterranean coastline municipalities [9]. For these reasons, in $200477 \%$ of the Mediterranean coastline municipalities, from Girona to Almería, were managed by private companies, $17 \%$ by public companies and $6 \%$ by mixed companies [10]. These ratios contrast with national percentages for the year 2000 , when $49 \%$ of municipalities were managed by private companies, $32 \%$ by public and $12 \%$ by mixed companies.

This situation continues evolving, since in recent years two antagonistic trends are taking place in the Spanish urban water governance. In the first place, the management of some supramunicipal entities responsible for upstream water supply has been privatized due to its high public debt accumulated by the construction of large infrastructures and an inadequate financing structure [11]. Such is the case of Aigües del Ter-Llobregat in the province of Barcelona, which through a competitive bidding process was awarded to Acciona, a Spanish multinational company specialized in energy and infrastructure [12]. Another example is the Mancomunidad de Canales del Taibilla (MCT), located on the southeast of the Iberian Peninsula, because of its economic situation has deteriorated as a result of the construction of desalination plants [13]-[15], although its privatization has not yet occurred.

In the second place, remunicipalization processes of urban water services are beginning to take place as a consequence of irregularities in the service, the end of the concession contracts and the arrival of left-wing parties to the municipal governments. While does not reach the French development level [16], is a growing trend in Spain, particularly in Catalonia, where remunicipalization is been considering in large coastline cities like Barcelona [17] or Badalona [18].

\section{AIMS AND METHODS}

The aim of this work is to identify the supramunicipal entities responsible for upstream water supply and the companies in charge of the urban water supply in the Mediterranean coastline. This area of study is significant because of its economic and demographic importance, since it is the main tourist destination in Spain. In addition, the Mediterranean is a vulnerable area to water scarcity and due to climate change this situation can get worse, since it is expected to reduce its available water resources. The companies analysed have been grouped by business groups and its importance will be analysed in terms of municipalities and population supplied. Through cartographic representation this exercise will make possible to clearly discern the actors involved in urban water governance models at municipal and regional level. 
For data collection, firstly, a bibliographic consultation about Spanish urban water governance has been done. Subsequently, the results from a database carried out by the project "Urbanization and water metabolism in Alicante coastline: trend analysis for the period 2000-2010" (CSO2012-36997-CO2-02), funded by the Spanish Ministry of Economy and Concurrency, have been taken into account. This work required telephone contact with councils and companies responsible for urban water supply. From this database, the information collected was contrasted with data available on companies, business groups and supramunicipal entities websites. The result has been mapped by Spanish Mediterranean coast sectors, covering different Autonomous Communities: 1) The northern Mediterranean coast, where Catalonia is located; 2) The eastern Mediterranean coast that includes the Valencian Community and the Murcia Region; 3) The southern Mediterranean coast where Andalusia is located; and 4) The insular Mediterranean coast, which include the Balearic Islands.

\section{SPANISH URBAN WATER GOVERNANCE MODELS}

The results of the analysis, such as it is shown in Fig. 1, indicate that $83 \%$ of Spanish Mediterranean coastline population is supplied by the private sector. This percentage includes both private and mixed firms. The mixed firms are the form of ownership that supplies a large majority of urban customers, almost half of the Mediterranean coastline population. This is explained by the presence of mixed firms in the biggest coastline cities, such as Barcelona and its metropolitan area, Valencia or the larger cities in the province of Alicante. Public firms and councils, through direct water delivery, supply only to $17 \%$ of the population. The cases of EMASA and EMAYA both public companies of the cities of Málaga (Andalusia) and Palma de Mallorca (Balearic Islands) are particularly important, since they are supplying water to more than half of Mediterranean coastline population supplied by a public firm.

Concerning supramunicipal entities, it must be pointed out that provide water to $72 \%$ of coastline population. It has been noted that not all the entities or companies created are managed by public sector. This is the case of Aigües del Ter-Llobregat, managed by Acciona; the case of the Metropolitan entity of hydraulic services in Valencia (EMSHI), managed by Aguas de Valencia; or the municipal association of the Tropical Coast in Granada, which by a concession contract granted the regional and urban water service to Aguas y Servicios de la Costa Tropical de Granada, a company formed by Aqualia (the FCC group) and Acciona capital. This dual management is also carried out in some Andalusian municipalities by public companies such as GALASA, ACOSOL or ARCGISA, under the authority of supramunicipal entities.

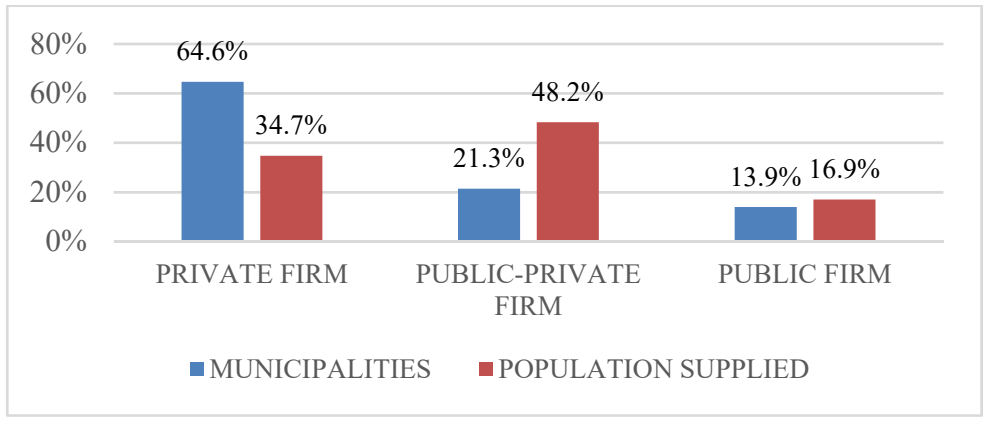

Figure 1: Share of population and municipalities supplied by type of firm. 
With regard to the main business groups involved in the urban water service the Agbar Group highlights above all. This group is owned by the French multinational Suez, and manages the service to $60 \%$ of private sector supplied population, or $50 \%$ of the total Mediterranean coastline population. The Agbar Group has different companies for each Autonomous Community and it is engaged in the main mixed firms located in Catalonia and in the province of Alicante.

Secondly, in terms of population supplied, is the Global Omnium Group, owner of the companies Aguas de Valencia and Aigües de Catalunya. This group supplies water to $14 \%$ of the population supplied by the private sector and to $11 \%$ of total Mediterranean coastline population. The third business group in terms of population supplied is the FCC Group, which through its subsidiary Aqualia manages the urban water service to $13.8 \%$ of the population supplied by a private firm. Other private companies with a lower share in the Mediterranean urban water management are FACSA in the province of Castellón, which is owned by the Gimeno Group, and Acciona. There are many other private companies, some of them established only locally, but are no significant in terms of population supplied.

The detailed analysis of the results by sectors of the Mediterranean coast is presented below.

\subsection{Northern Mediterranean coast: Catalonia}

In Catalonia the urban water service is managed by a private company in $70 \%$ of the municipalities, by mixed firms in $22.85 \%$ of the cases and by the public sector only in the $7.14 \%$ of the municipalities. However, in terms of population supplied the most relevant type of management is the mixed one, which provides the service to $72.53 \%$ of population, while private companies supply $18.86 \%$ and the public ones $8.59 \%$.

Considering the activity of the Agbar Group through its private company Sorea and as a partner in mixed companies, this group is present in $71 \%$ of the coastline municipalities and supplies water to $85 \%$ of the Catalonian coastline population, as it is shown in Fig. 2. To a

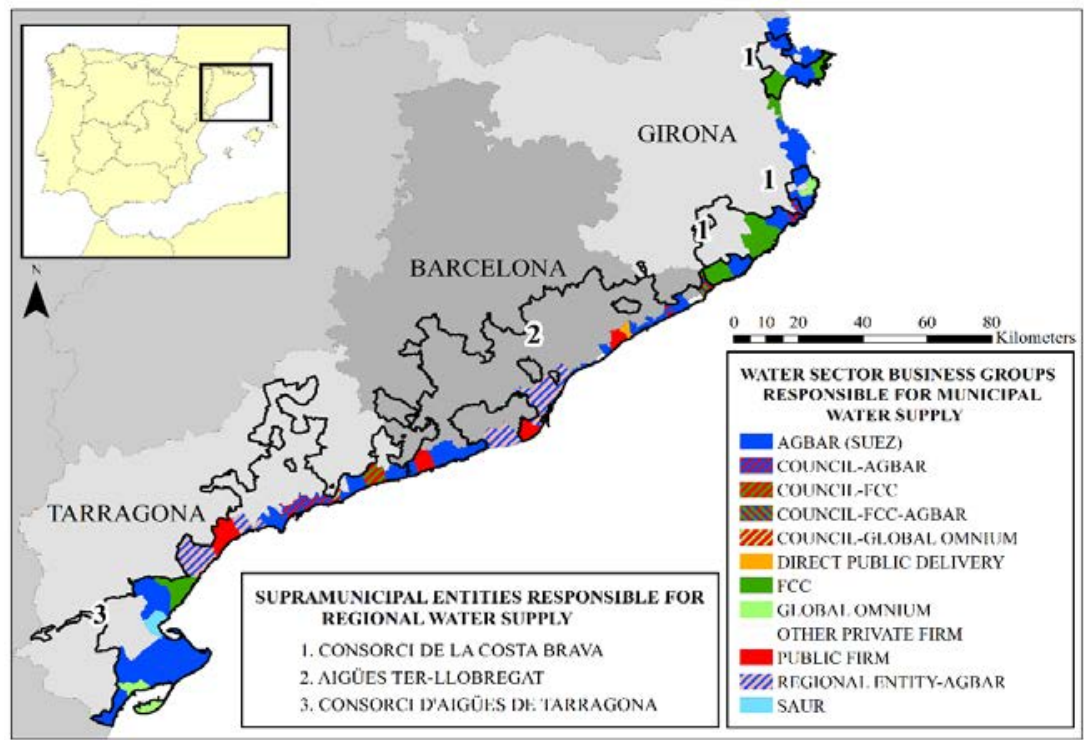

Figure 2: Urban water governance models in Spanish northern Mediterranean coast. 
large extent this is explained by the involvement of the Agbar Group in the mixed company Aigües de Barcelona together with Criteria CaixaCorp S.A. and the Association of municipalities of the Barcelona metropolitan area, entailing almost two thirds of the Catalonian coastline population.

There is a large presence of FCC Group in the province of Girona, where manages one third of the coastline municipalities and supplies to, likewise, a third of the population. However, at the regional level, only $5.3 \%$ of the Catalonian coastline population is supplied by this group, counting on its participation in mixed firms. Public Companies and Global Omnium Group, through the company Aigües de Catalunya, supply water to $8.5 \%$ and $0.7 \%$ of the coastline population, respectively.

Finally, the supramunicipal entities supply upstream water to $82 \%$ of the Catalonian coastline population. These entities are, firstly, the Consorcio de la Costa Brava located in the province of Girona. It was set up in 1971 by the provincial council and the coastline councils and serves water to 27 municipalities, which together make up $67 \%$ of Girona's coastline population. Secondly, in the province of Barcelona is Aigües del Ter-Llobregat, which supplies water at least to $80 \%$ of the coastline population of this province. Thirdly, is the Consorci d'Aigües de Tarragona, created in 1985 by the regional administration, councils, several industries and irrigation communities of the province, provides water to all the coastline municipalities of this province.

\subsection{Eastern Mediterranean coast: community of Valencia and the Region of Murcia}

In the eastern Mediterranean coastline are located the major presence of private companies, since they manage the urban water service in $79 \%$ of the municipalities. Nevertheless, the biggest cities water services are managed by mixed companies, such as Alicante, Elche, Torrevieja or Valencia. This is why the mixed companies supply water to $52 \%$ of the coastline population while private companies provide water to $45 \%$. The presence of public companies is the lowest in the whole Mediterranean coastline, identifying only three municipalities which represent $2 \%$ of the coastline population.

Again, the Agbar Group manages a larger number of municipalities and serves water to a greater share of coastline population, as it is shown in Fig. 3. Through its subsidiaries Hidraqua and Hidrogea in the Community of Valencia and Region of Murcia, respectively, the Agbar Group supplies water to $45 \%$ of eastern Mediterranean coastline population. Likewise, relying exclusively on the provinces of Alicante and Murcia, the Agbar Group manages both in private and mixed firms the urban water service to $86 \%$ and $80 \%$ of the coastline population respectively.

In the two other provinces, Valencia and Castellón, the situation is characterized by the regional specialization of two domestic capital business groups. In Valencia, the company Aguas de Valencia, owned by the Global Omnium Group, supplies water to $89 \%$ of the coastline population in the province of Valencia and to $34.9 \%$ of the total coastline population in this Mediterranean sector. In addition, it manages the supramunicipal entity EMSHI by means of the Metropolitan Mixed Company (EMIMET). In Castellon, the companies FACSA and to a lesser extent FOBESA, both owned by the Gimeno Group, hold the urban water management for almost the whole coastline of this province.

In eastern Mediterranean coastline, the relevance of the upstream supply systems formed by consortiums, municipal association or metropolitan entities is similar to Catalonia, since supply water to $81.1 \%$ of coastline population. In the provinces of Alicante and Murcia, where there is a strong water deficit, all the coastline municipalities are attached to a 

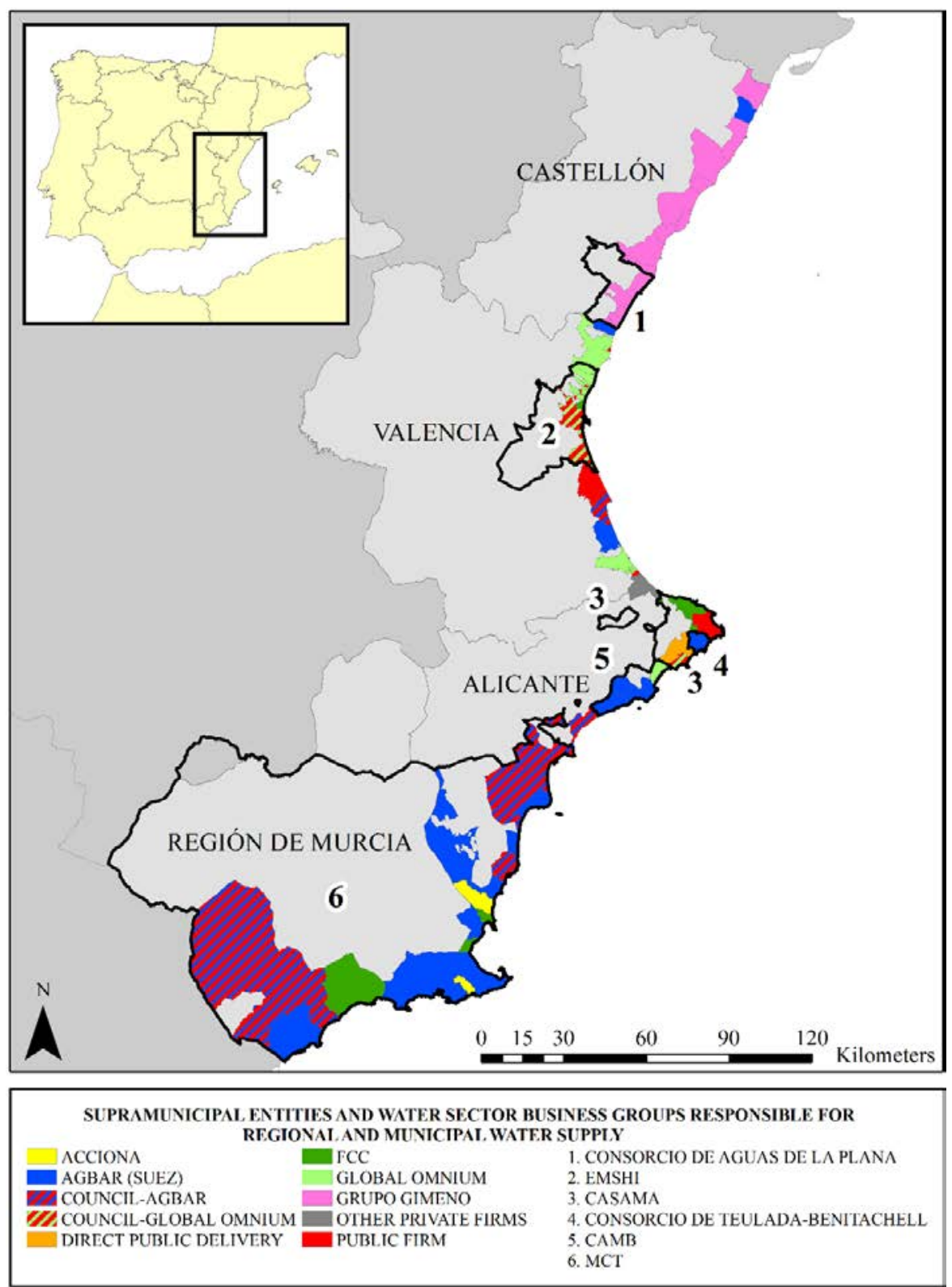

Figure 3: Urban water governance models in Spanish eastern Mediterranean coast.

supramunicipal entity. The degree of efficiency varies greatly between entities: the Consorcio de Aguas de la Marina Alta (CASAMA) is practically inoperative while the MCT and the Consorcio de Aguas de la Marina Baja (CAMB) have decades of experience managing upstream supply systems [13], [14]. Finally, in the province of Valencia the EMSHI supplies upstream water to $77.5 \%$ of the coastline population, while in the province of Castellón the Consorcio de Aguas de la Plana only serves water to $15 \%$ of the coastline population. 


\subsection{Southern Mediterranean coast: Andalusia}

In the Andalusian Mediterranean coastline, live around a quarter of the total population of this Autonomous Community. The main populations are located in the provinces of Almería and Málaga, partly due to the location of their provincial capital cities in the coastline. The major part of municipalities (58\%) and the population supplied (46\%) have an urban water service managed by a private company. However, the water public sector is relevant, since manages the urban water service to $38 \%$ of the coastline population, as a result of the public management in Málaga city. The mixed firms have not reached great development, managing the service only to $15 \%$ of the coastline population.

Regarding business groups involved in the urban water management, FCC Group stands out, because it is present in $43 \%$ of the municipalities and supplies $26 \%$ of the coastline population. It has a strong presence in the province of Almería, where manages the capital city water service as well as in the province of Granada, where manages the service of the entire coastline together with Acciona. Also has a remarkable presence in the province of Cádiz, managing the service in the city of Algeciras by means of a mixed firm called EMALGESA.

The Agbar Group has a reduced presence beside the other Mediterranean coastline sectors analysed. Nevertheless, it is present in $20 \%$ of the municipalities supplying water to a similar percentage of coastline population, through its Andalusian subsidiary Hidralia.

Regarding supramunicipal entities, there are a substantial number of them, as it is shown in Fig. 4. However, only provide water to half of the Andalusian Mediterranean coastline population. The majority of them are public firms created by different municipal associations (ARCGISA, ACOSOL, AXARAGUA, GALASA), although Aguas y Servicios de la Costa Tropical de Granada is a private one. In the provinces of Cádiz and Granada, these supramunicipal companies supply water to all municipalities, while those situated in the province of Málaga and Almería provide water to $54 \%$ and less than $20 \%$ of that coastline population, respectively.

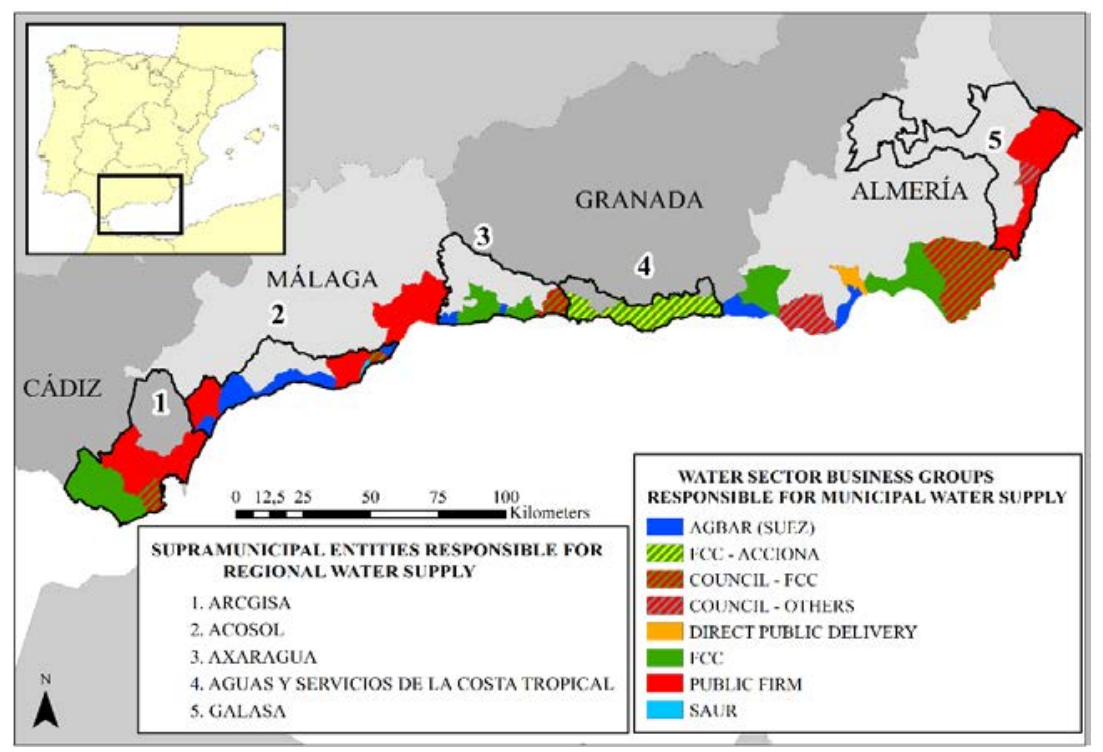

Figure 4: Urban water governance models in Spanish southern Mediterranean coast. 


\subsection{Insular Mediterranean coast: Balearic Islands}

The urban water governance model in the Balearic Islands is quite different from the rest of the Spanish Mediterranean coastline. The reasons for these differences are diverse. First of all, it must be pointed out the insular conditions that cause the concentration of $85 \%$ of the Balearic population along coastline. Secondly, there is a greater dependence on groundwater resources than in other areas of the Mediterranean, as they represent two thirds of the available water resources [19]. The surface resources are limited to $2 \%$ of the total available, and they are located in the island of Mallorca, reserved for the capital city's water supply. This situation has created an early development of the desalination, which was begun earlier than in peninsular Spain. Currently, eight desalination plants distributed throughout the islands provide $14 \%$ of available water resources. In addition, the Balearic Islands wastewater treatment is quite developed and a significant part is reused for agricultural and urban uses as well as for the irrigation of golf courses [19]. For these reasons, given the need to have a supramunicipal entity which manage and promote the hydraulic infrastructures, the Balearic water and environmental quality agency (ABAQUA) was created in 2004. This entity supplies water in the northern half of Mallorca Island to $55 \%$ of total Balearic coastline population, approximately. Although it is a public agency, the management of the upstream service has been granted to FACSA, the company owned by the Gimeno Group [20], and the desalination and wastewater treatment to different companies including UTE CODEISA, formed by Aqualia-FCC and Acciona, or Dergemont, owned by Suez.

Another unique characteristic is the lack of mixed firms, as shown in Fig. 5. Instead of mixed companies, in $40 \%$ of the municipalities the supply of water is managed by different companies simultaneously and independently in each population centre within the same municipality. This one supplies water to $26.9 \%$ of Balearic coastline population. This might be explained because of the generalization of urban sprawl models and the dependence on highly localized groundwater resources, which supply coastal urbanizations.

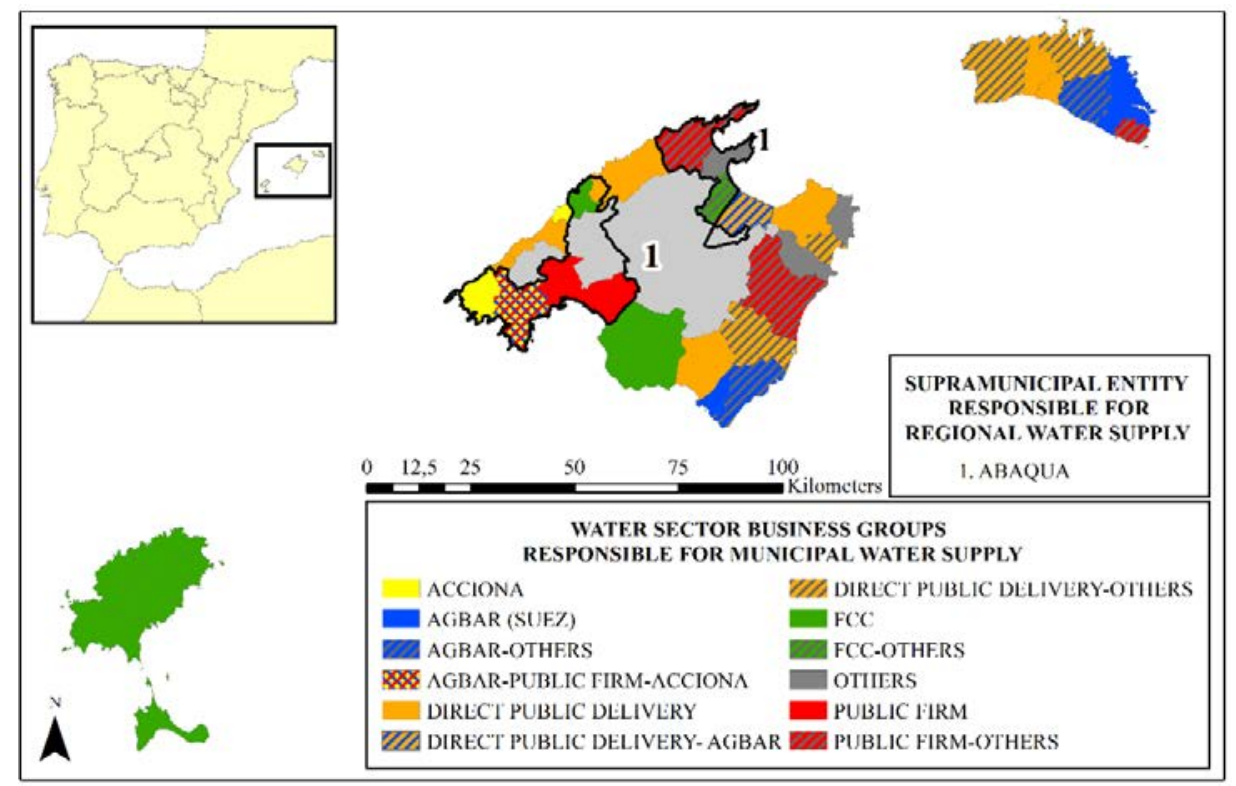

Figure 5: Urban water governance models in Spanish insular Mediterranean coast. 
Apart from that, in $34 \%$ of the municipalities all the companies are private. This proportion is quite low in comparison with other coastline sector, and only supply water to $27.1 \%$ of the Balearic coastline population. When several companies are located within a municipality, normally the council performs the direct water delivery for the main population centre, typically situated inland. In fact, in the Balearic Islands exists the greater share of direct public delivery of the Mediterranean coastline, present in $23 \%$ of municipalities. Nevertheless these municipalities tend to be smaller, since represent only $2.9 \%$ of the Balearic coastline population.

EMAYA, the public company responsible for the water service in Palma de Mallorca, is the Balearic major company, supplying water to $43 \%$ of coastline population. In terms of population supplied, FCC Group is in second place, as supplies water to $22 \%$ of coastline population. It should also be emphasized that this group is spatially concentrated in the islands of Ibiza and Formentera, where it also manages desalination plants. The Agbar Group through its subsidiary in Balearic Islands, Hidrobal, manages the urban water service for $12.9 \%$ of the coastline population, its lowest share in the Mediterranean coastline.

\section{CONCLUSIONS}

From the analysis of the urban water governance models across the Spanish Mediterranean coastline several conclusions emerge. On the one hand, it is noted that a corporate concentration and an oligopolistic structure exist. The Agbar Group supplies water in 40\% of Spanish Mediterranean coastline municipalities and in almost half of them that have decided to privatize the service. In terms of population supplied, this group provides water to half of the Mediterranean coastline population, and to $60 \%$ of the population residing in municipalities where the private sector is present. Secondly, the FCC Group through its subsidiary Aqualia, supplies water in $19.5 \%$ of the Spanish Mediterranean coastline municipalities. These groups together with Global Omnium Group, supply water to $73.6 \%$ of the Spanish Mediterranean coastline population, while the entire private sector supplies water to $83 \%$.

On the other hand, it has been shown that there is a regional specialization of these business groups [10]. This cause a lack of competence in public bidding processes, since the companies already established in the area are more able to promote the development of economies of scale and implementing more competitive offers [1]. The Agbar Group is specially concentrated in Catalonia, Alicante and Murcia, while the FCC Group is in Girona, Balearic Islands and Andalusia. Likewise, there is a severe regional specialization of other companies, such as Aguas de Valencia (Global Omnium Group) in the Valencia province or FACSA (Gimeno Group) in Castellón province. Nevertheless, two coastline sectors are well differentiated according to the presence of private sector. In the northern and eastern Mediterranean sectors, private and mixed companies have a market share higher than $90 \%$, in terms of population and municipalities supplied. In Andalusia and Balearic Islands, by contrast, the private sector is not yet so developed, since $26 \%$ and $30 \%$ of municipalities, respectively, are managed by public sector supplying water to the $38 \%$ and $45 \%$ of the coastline population.

The evolution of the Spanish urban water governance remains uncertain, although the private sector presence has grown over the last few decades diversifying their range of activities, managing desalination and wastewater treatment plants or even upstream supply systems. Notwithstanding, the development of the remunicipalization processes initiated in Catalonia might involve an important change in this trend for years to come. 


\section{ACKNOWLEDGEMENTS}

This paper is a result of a pre-doctoral fellowship (FPU/01144), granted by the Spanish Ministry of Education, Culture and Sport, in the subprograms of Training and Mobility included in the State Program for Promotion of Talent and its Employability, within the framework of the State Plan for Scientific and Technical Research and Innovation 2013-2016. Likewise, it is inserted in the research project "Use and Management of unconventional water resources on the coast of the regions of Valencia and Murcia as a strategy for adaptation to drought" (CSO2015-65182-CS-2-P) funded by the Ministry of Economy and Competitiveness.

\section{REFERENCES}

[1] González-Gómez, F., García-Rubio, M.A. \& González-Martínez, J., Beyond the public-private controversy in urban water management in Spain. Utilities Policy, 31, pp. 1-9, 2014.

[2] Saurí, D., Olcina, J. \& Rico, A.M., The march towards privatisation? Urban water supply and sanitation in Spain. Journal of Comparative Social Welfare, 23(2), pp. 131139, 2007.

[3] Castro, V. \& Janssens, J.G., Mixed Private-Public Ownership companies "Empresa Mixta". Public-Private-Partnership in Infrastructure Resource Center for Contracts, Laws and Regulations (PPPIRC), World Bank Group. Online, https://ppp.worldbank.org/public-private-partnership/library/mixed-private-publicownership-companies-empresa-mixta. Accessed on: 1 Mar. 2017.

[4] Bel, G. \& Fageda, X., Why do local governments privatize public services? A survey of empirical studies. Local Government Studies, 33(4), pp. 517-534, 2007.

[5] Bel, G. \& Fageda, X., Factors explaining local privatization: a meta-regression analysis. Public Choice, 139, pp. 105-119, 2009.

[6] Pérard, E., Water supply: Public or private?. An approach based on cost of funds, transaction costs, efficiency and political costs. Policy and Society, 27(3), pp. 193219, 2009.

[7] Ruiz-Villaverde, A., García-Rubio, M.A. \& González-Gómez, F., Analysis of urban water management in historical perspective: Evidence for the Spanish case. International Journal of Water Resources Development, 26(4), pp. 653-674, 2010.

[8] González-Gómez, F., A duration model for the estimation of the contracting out of urban water management in southern Spain. Urban Affairs Review, 44(6), pp. 886906, 2009.

[9] Instituto Nacional de Estadística (INE), Cifras oficiales de población de los municipios españoles: Revisión del Padrón municipal a 1 de enero de 2016. www.ine.es. Accessed on: 13 Feb. 2017.

[10] Del Romero, L., Privatització de la gestió de l'aigua i govern del territori a l'arc mediterrani espanyol. Documents d'Analisi Geografica, 48, pp. 35-59, 2006.

[11] March, H., La nova guerra de l'aigua a Barcelona: Austeritat, deute i participació privada. Documents d'Analisi Geografica, 60(3), pp. 505-521, 2014.

[12] March, H. \& Saurí, D., The unintended consequences of ecological modernization: Debt-induced reconfiguration of the water cycle in Barcelona. Environment and Planning A, 45(9), pp. 2064-2083, 2013.

[13] March, H., Saurí, D. \& Rico-Amorós, A.M., The end of scarcity? Water desalination as the new cornucopia for Mediterranean Spain. Journal of Hydrology, 519(PC), pp. 2642-2651, 2014. 
[14] Rico, A.M., La Mancomunidad de los Canales del Taibilla: un modelo de aprovechamiento conjunto de fuentes convencionales y desalinización de agua marina. Libro Jubilar en Homenaje al Profesor Antonio Gil Olcina, coords. J. Olcina \& A.M. Rico, Instituto Interuniversitario de Geografía-Universidad de Alicante: San Vicente del Raspeig, pp. 367-394, 2016.

[15] Arahuetes, A., Villar, R. \& Hernández, M., El ciclo hidrosocial en la ciudad de Torrevieja: retos y nuevas tendencias. Revista de Geografía Norte Grande, 65, pp. 109-128, 2016.

[16] Kishimoto, S., Lobina, E. \& Petitjean, O. (eds.), Our public water future: The global experience with remunicipalisation. Transnational Institute; Public Services International Research Unit; Multinationals Observatory; Municipal Services Project y European Federation of Public Service Unions: Amsterdam, London, Paris, Ciudad del Cabo y Bruselas, 132 pp., 2015.

[17] La Vanguardia, Barcelona estudiará la remunicipalización del suministro de agua, 25 Nov. 2016. http://www.lavanguardia.com/local/barcelona/20161125/412162199077 /barcelona-estudiara-remunicipalizar-agua.html. Accessed on: 3 Mar. 2017.

[18] La Vanguardia, El Ayuntamiento de Badalona aprueba iniciar la remunicipalización del agua, 3 Feb. 2017. http://www.lavanguardia.com/local/barcelonesnord/20170203/ 413974283750/ayuntamiento-badalona-aprueba-iniciar-remunicipalizacion-aguaservicio.html. Accessed on: 4 Mar. 2017.

[19] Direcció General de Recursos Hídrics, Conselleria de Medi Ambient, Agricultura i Pesca. Memoria del proyecto del plan especial de actuación en situaciones de alerta y eventual sequía en las Illes Balears, version 2 January 2017. https://www.caib.es/sacmicrofront/contenido.do?idsite=259\&cont=23087\&lang=es. Accessed on: 10 Mar. 2017.

[20] Grupo Gimeno. Online, http://www.grupogimeno.com 